\title{
SALICYLIC ACID AND GIBBERELIC ACID AMELIORATES THE ADVERSE EFFECTS OF SALINITY ON CHICKPEA
}

\author{
M. I. Hossain ${ }^{1}$, M. A. Mannan ${ }^{2 *}$ and M. A. Karim ${ }^{3}$ \\ ${ }^{1}$ Assistant Director, BADC, Bangladesh; $2 \& 3$ Department of Agronomy, Bangabandhu Sheikh Mujibur Rahman \\ Agricultural University, Gazipur-1706, Bangladesh. \\ "Corresponding author: mannanbsmrau@yahoo.com
}

Key words: Salicylic acid, gibberelic acid, ameliorates adverse effects, salinity and chickpea

\begin{abstract}
A pot experiment was carried out under semi-controlled environmental condition in the Department of Agronomy, Bangabandhu Sheikh Mujibur Rahman Agricultural University, Gazipur, Bangladesh during December 2012 through March 2013 aiming to alleviate the salinity stress effects on chickpea using salicylic acid (SA) and gibberelic acid $\left(\mathrm{GA}_{3}\right)$. Chickpea variety BARI Chola-5 was used in the experiment. Salt solution was prepared by adding tap water in sea water to make $5,7.5$ and $10 \mathrm{dS} \mathrm{m} \mathrm{m}^{-1}$ salinity level. Plants were irrigated with $5,7.5$ and $10 \mathrm{dSm}^{-1}$ concentrations of saline water from $14^{\text {th }}$ days after sowing (DAS) to maturity (100 DAS) and control plants were irrigated with tap water. Different concentration of SA (200 ppm and $400 \mathrm{ppm}$ ) and $\mathrm{GA}_{3}$ (10 ppm and $20 \mathrm{ppm}$ ) were applied as foliar spray once in a week from 20 DAS to flowering stage. The data for chlorophyll content in leaf and water relation traits such as relative water content (RWC) and water retention capacity (WRC) were measured 7 days after foliar spray of plant growth regulators at flowering stage. Total dry weight (root+shoot), yield and yield contributing characters were measured at maturity. Results indicated that salinity decreased total dry weight, chlorophyll content, relative water content, water retention capacity and yield of chickpea. Foliar application of $\mathrm{SA}$ and $\mathrm{GA}_{3}$ at different doses under different salinity conditions had the positive effects related to mitigation of salinity stress effect but low concentration i.e., SA and $\mathrm{GA}_{3} @ 200$ ppm and $10 \mathrm{ppm}$, respectively were found to alleviate the adverse effects significantly on the above parameters at low salinity condition $\left(5 \mathrm{dSm}^{-1}\right)$.
\end{abstract}

\section{Introduction}

The reduction in plant growth exposed to saline environments could be due to either the effects of specific ions on metabolism or adverse water relations (Kaya et al., 2009). Different strategies are being employed to maximize plant growth under saline conditions. One of them is to produce salt tolerant genotypes of different crops. Attempts to improve tolerance to salinity through conventional plant breeding methods are time consuming, laborious and dependent on existing genetic variability. An alternative approach for coping with salinity could, therefore, be an exogenous application of growth regulators which diminish salinity effect in plant to a tolerable level. Plant growth regulators like salicylic acid (SA) and gibberelic acid $\left(\mathrm{GA}_{3}\right)$ are recognized endogenous regulator of plant metabolism, which mainly involved in biotic and abiotic stress (Aydin and Nalbantoglu, 2011). Exogenous SA could regulate the activities of antioxidant enzymes and increase plant tolerance to abiotic stresses (He et al., 2002; Erasalan et al., 2007). Gibberelic acid regulates growth and development to the plants and to be helpful in enhancing growth of development of wheat and rice under saline conditions (Schwechheimer, 2008). Maggio et al. (2010) reported that $\mathrm{GA}_{3}$ treatment in tomato reduced stomatal resistance and enhanced plant water use at low salinity. 
Hossain et al.

Chickpea (Cicer arietinum L.) is an annual grain legume or "pulse crop" that is known as 'Chola' in Bangladesh is mainly used for human consumption as well as for animal feeds. Chickpea seeds contain 21\% protein, 5.6\% fat, 60\% carbohydrate, and are rich in minerals and vitamins. Chickpea is a salt-sensitive crop, and yields are seriously reduced by salinity (Manchanda and Sharma, 1990). The information regarding the action of salicylic acid and gibberelic acid in enhancing salt tolerance and growth of chickpea is not enough for making any concrete recommendation to the end-users. A very limited works have been carried out regarding the use of growth regulators like $\mathrm{SA}$ and $\mathrm{GA}_{3}$ on chickpea varieties in relation to salinity tolerance in Bangladesh. Therefore, the present study was undertaken to evaluate the effects of $\mathrm{SA}$ and $\mathrm{GA}_{3}$ to enhance salinity tolerance of chickpea.

\section{Materials and Methods}

A pot experiment was conducted under semi-controlled environmental condition in the Department of Agronomy, Bangabandhu Sheikh Mujibur Rahman Agricultural University, Gazipur during from December 2012 to March 2013. The soil used in the experiment was clay loam in texture with neutral in nature and poor fertility status. Chickpea variety BARI Chola 5 was used in the experiment. Ten seeds were sown in each plastic pots of $24 \mathrm{~cm}$ (diameter) X $30 \mathrm{~cm}$ (height) in size filled with soil inside plastic house under natural light. Compost (25\% of the soil volume) and 0.27-0.28-0.20 g of urea, triple super phosphate and muriate of potash per pot for supplying $\mathrm{N}, \mathrm{P}_{2} \mathrm{O}_{5}$ and $\mathrm{K}_{2} \mathrm{O}$, respectively were incorporated uniformly into the soil. The compost was made mostly from cow dung which contained $0.8 \% \mathrm{~N}, 0.6 \% \mathrm{P}_{2} \mathrm{O}_{5}$ and $1.0 \%$ $\mathrm{K}_{2} \mathrm{O}$ on dry weight basis. After seedling establishment, five uniform and healthy plants were allowed to grow in each pot. Weeding and pest control measures were taken for proper growth of plants. Salt solution was prepared by adding tap water in sea water to make 5, 7.5 and 10 $\mathrm{dSm}^{-1}$ salinity level. Plants were irrigated with these 5, 7.5 and $10 \mathrm{dSm}^{-1}$ concentrates saline water from $14^{\text {th }}$ days after sowing (DAS) to maturity (100 DAS) and control plants were irrigated with tap water. Different concentration of $\mathrm{SA}$ and $\mathrm{GA}_{3}$ were applied as foliar spray once in a week from 20 DAS to flowering stage. The treatments of the experiment were: $\mathrm{i}$. Control (non saline condition) ii. $5 \mathrm{dSm}^{-1}$ salinity iii. $7.5 \mathrm{dSm}^{-1}$ salinity iv. $10 \mathrm{dSm}^{-1}$ salinity v. 5 $\mathrm{dSm}^{-1}$ salinity +200 ppm SA vi. $7.5 \mathrm{dSm}^{-1}$ salinity $+200 \mathrm{ppm} \mathrm{SA}$ vii. $10 \mathrm{dSm}^{-1}$ salinity + 200 ppm SA viii. $5 \mathrm{dSm}^{-1}$ salinity +400 ppm SA ix. $7.5 \mathrm{dSm}^{-1}$ salinity +400 ppm SA x. 10 $\mathrm{dSm}^{-1}$ salinity +400 ppm SA xi. $5 \mathrm{dSm}^{-1}$ salinity $+10 \mathrm{ppm} \mathrm{GA}_{3}$ xii. $7.5 \mathrm{dSm}^{-1}$ salinity +10 ppm $\mathrm{GA}_{3}$ xiii. $10 \mathrm{dSm}^{-1}$ salinity +10 ppm GA 3 xiv. $5 \mathrm{dSm}^{-1}$ salinity +20 ppm $\mathrm{GA}_{3}$ xv. 7.5 $\mathrm{dSm}^{-1}$ salinity +20 ppm GA 3 and xvi. $10 \mathrm{dS} \mathrm{m}^{-1}$ salinity $+20 \mathrm{ppm} \mathrm{GA}_{3}$. The data for chlorophyll content and water relation traits in leaf such as relative water content (RWC) and water retention capacity (WRC) were recorded 7 days after foliar spray of $\mathrm{SA}$ and $\mathrm{GA}_{3}$ at flowering stage. Chlorophyll content was estimated from the fully expanded uppermost leaf samples using the method described by Witham et al. (1986).

To measure the relative water content (RWC), fresh weight of the collected leaves sample was measured immediately. Thereafter, the leaves were immersed in distilled water for 24 hours at room temperature in the dark. These leaves were weighed to record the turgid (saturated) weight after excess water was removed, by gently wiping the leaves with a paper towel. The leaves were then dried in an oven for 48 hours at $72{ }^{\circ} \mathrm{C}$ to determine their dry weight. The values of the fresh, turgid and dry weights of the leaves were used to calculate RWC $=(\mathrm{FW}-$ DW) / (TW-DW) X 100, Where, FW = Fresh weight of the leaf, DW = Dry weight of the leaf, TW = Turgid weight of the leaf. Water retention capacity is the ratio of the turgid weight and dry weight of a leaf. After the harvest both treated and controlled plants were segmented into 
different components (root, stem, leaf). The segmented parts were then oven dried for 72 hours and the dry weights were recorded. Total dry weight of both treated and control plant were estimated by summing up the dry weight of root, stem and leaf. Pods were collected from the plant and data were recorded on number of pod plant ${ }^{-1}$, number of seed $\operatorname{pod}^{-1}, 100$ seed weight and seed yield plant ${ }^{-1}$ in case of both treated as well as control plants in each pot. The data recorded on different parameters were statistically analyzed with the help of MSTAT-C program. Means were compared to adjust the difference in plant performance under growth regulators treatments experiencing both salinity and control conditions by Least Significant Different Test (Gomez and Gomez, 1984).

\section{Results and Discussion}

\section{Total dry weight}

Dry matter accumulation was decreased significantly with an increasing salinity levels. It was found that control plant produced highest total dry matter (17.94 g plant ${ }^{-1}$ ) and under $5 \mathrm{dSm}^{-1}$ saline condition it was (14.68 g plant-1). Minimum total dry weight was found at $10 \mathrm{dSm}^{-1}$ saline condition (12.48 g plant ${ }^{-1}$ ), which was only $69 \%$ of the control (Fig. 1). Total dry weight increased when foliage was sprayed with $\mathrm{SA}$ and $\mathrm{GA}_{3}$ at different rates under salinity stress. $16.00 \mathrm{~g} \mathrm{plant}^{-1}$ dry matter was obtained when plant was sprayed with SA @ 200 ppm, followed by $15.40 \mathrm{~g} \mathrm{plant}^{-1}$ when plant was sprayed with $\mathrm{GA}_{3} @ 10$ ppm under $5 \mathrm{dSm}^{-1}$ salt treated plants. When plant was sprayed with SA @ 400 ppm and $\mathrm{GA}_{3} @ 20$ ppm total dry matter plant ${ }^{-1}$ was found $14.8 \mathrm{~g}$ and $14.49 \mathrm{~g}$, respectively under the same $\left(5 \mathrm{dSm}^{-1}\right)$ salinity condition. At $10 \mathrm{dSm}^{-1}$ saline condition when plant was sprayed with SA @ $200 \mathrm{ppm}$ and $\mathrm{GA}_{3}$ @ $10 \mathrm{ppm}$, dry matter production was $12.79 \mathrm{~g}$ and $13.29 \mathrm{~g} \mathrm{plant}^{-1}$, respectively. On the other hand, when plant was sprayed with SA @ 400 ppm and GA $@ 20$ ppm dry matter production was $12.5 \mathrm{~g}$ and $12.91 \mathrm{~g}$ plant ${ }^{-1}$, respectively under the same $\left(10 \mathrm{dSm}^{-1}\right)$ salinity stress. Lower doses of $\mathrm{SA}$ and $\mathrm{GA}_{3}$ show remarkable effect on dry matter production under saline condition. Simillar results also reported by Yildirim et al. (2008) and Hussien et al. (2007) who reported that exogenous application of SA ameliorated the negative effect of salt stress on dry weight of plants. Our results are in agreement with the findings of Ashraf et al. (2002) who that $\mathrm{GA}_{3}$ in salt stressed plants showed an increased photosynthetic capacity- a vital factor for higher dry matter synthesis.

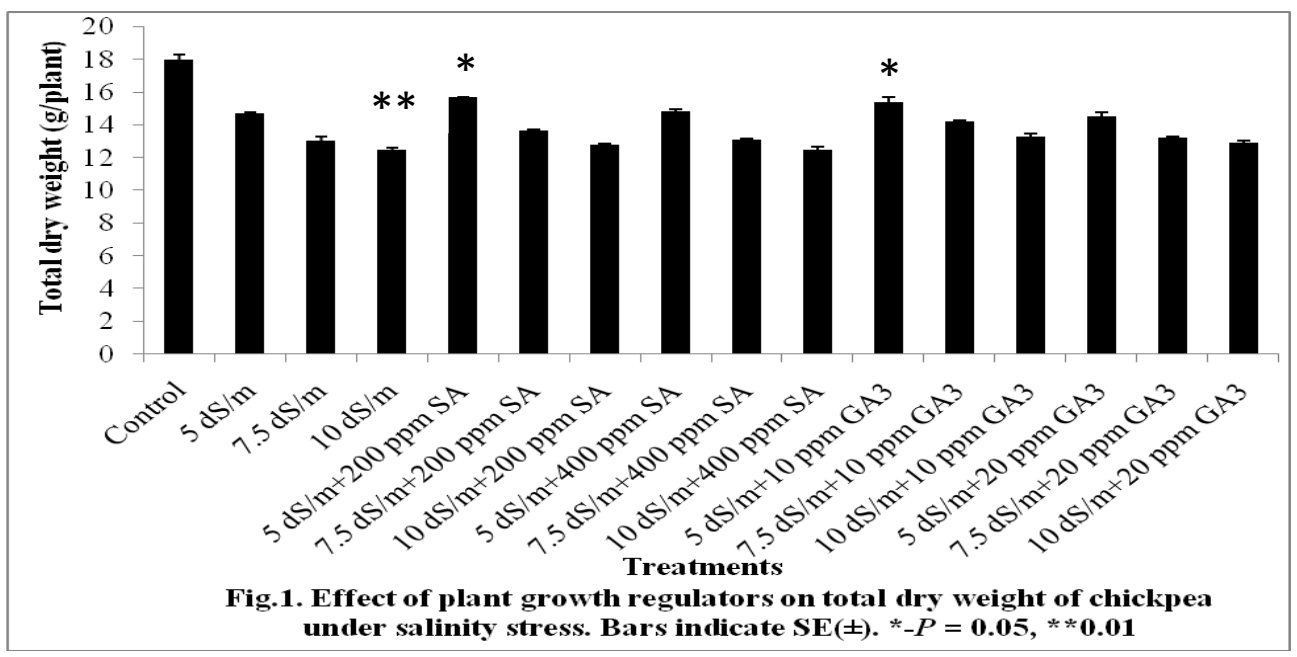


Hossain et al.

\section{Relative water content}

Relative water content was low under saline conditions compared to control (Fig. 2). Control plant maintained highest RWC (85\%). Under saline condition, RWC\% decreased and decreasing rate was higher with increasing salinity levels. At 5, 7.5 and $10 \mathrm{dSm}^{-1}$ salinity conditions RWC were 80\%, 76\% and 68\%, respectively. However, foliar application of SA and $\mathrm{GA}_{3}$ increased the RWC under different salinity conditions. When plant was sprayed with SA @ 200 ppm and $\mathrm{GA}_{3} @ 10$ ppm RWC was 83\% and 80\%, respectively under $5 \mathrm{dSm}^{-1}$ salinity condition. At $10 \mathrm{dSm}^{-1}$ saline condition when plant was sprayed with SA @ $200 \mathrm{ppm}$ and $\mathrm{GA}_{3}$ @ 10 ppm, RWC was 69\% and 68\%, respectively. On the other hand, when plant was sprayed with SA @ 400 ppm and $\mathrm{GA}_{3} @ 20$ ppm RWC was 66 and 67\%, respectively under the same salinity $\left(10 \mathrm{dSm}^{-1}\right)$ stress. So RWC increasing rate was lower when plant was sprayed with higher doses of $\mathrm{SA}$ and $\mathrm{GA}_{3}$. The results are in close conformity of the fact that SA potentially generates a wide array of metabolic responses in plants and also affects plant water relations (Hayat et al., 2010).

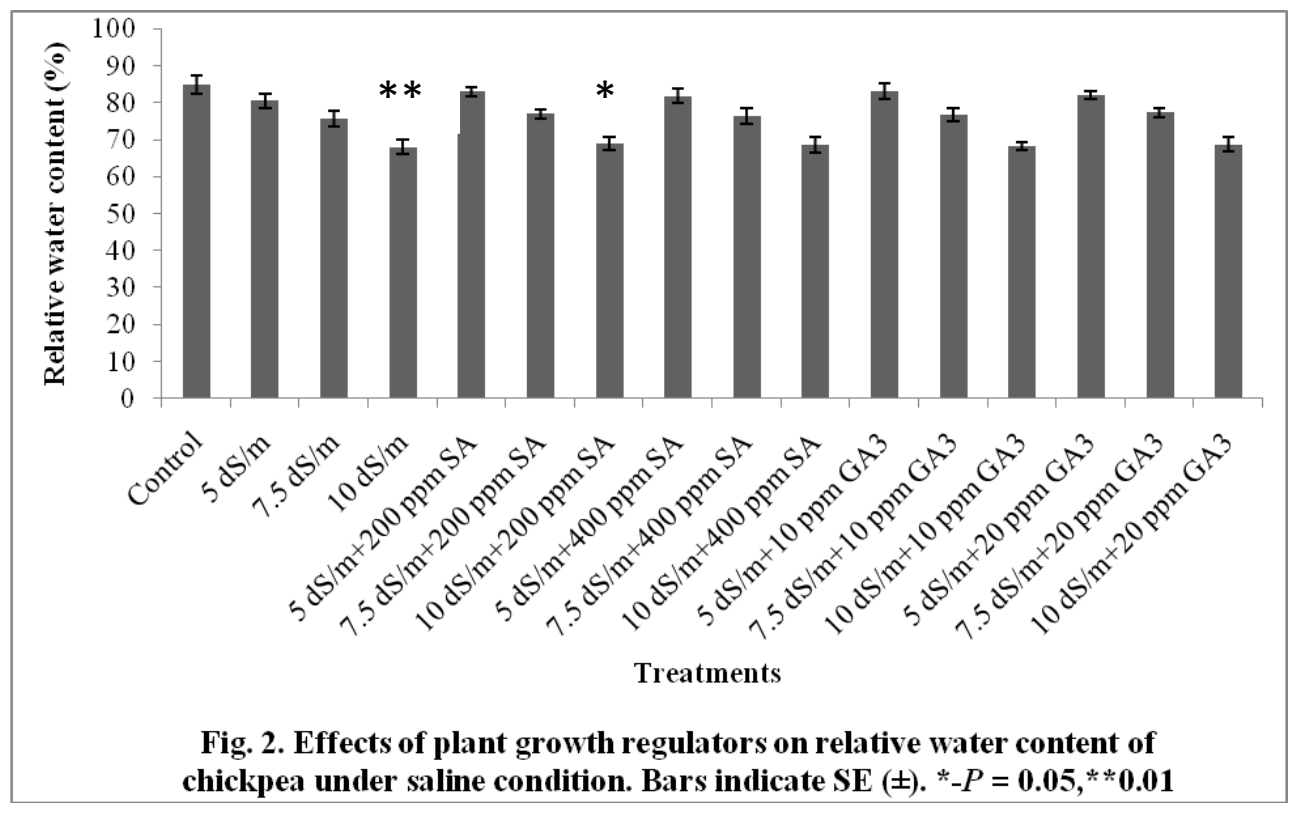

\section{Water retention capacity}

Water retention capacity is the ratio of the turgid weight and dry weight of a tissue. Control plants (non saline condition) maintained the maximum WRC (about 7.0) than the saline treated plants and it was gradually decreased with the increased salinity level. Under $10 \mathrm{dS} / \mathrm{m}$ salinity level it was 3.8. SA and $\mathrm{GA}_{3}$ enhance the salinity tolerance and increase the water retention capacity (Fig. 3) and increasing rate was higher when plant was sprayed with $200 \mathrm{ppm}$ SA and $10 \mathrm{ppm} \mathrm{GA}_{3}$ under $5 \mathrm{dS} / \mathrm{m}$ saline condition. Ahmad et al. (2009) reported in their study that application of $\mathrm{GA}_{3}$ counteracted the adverse effects of $\mathrm{NaCl}$ salinity on relative water content. 


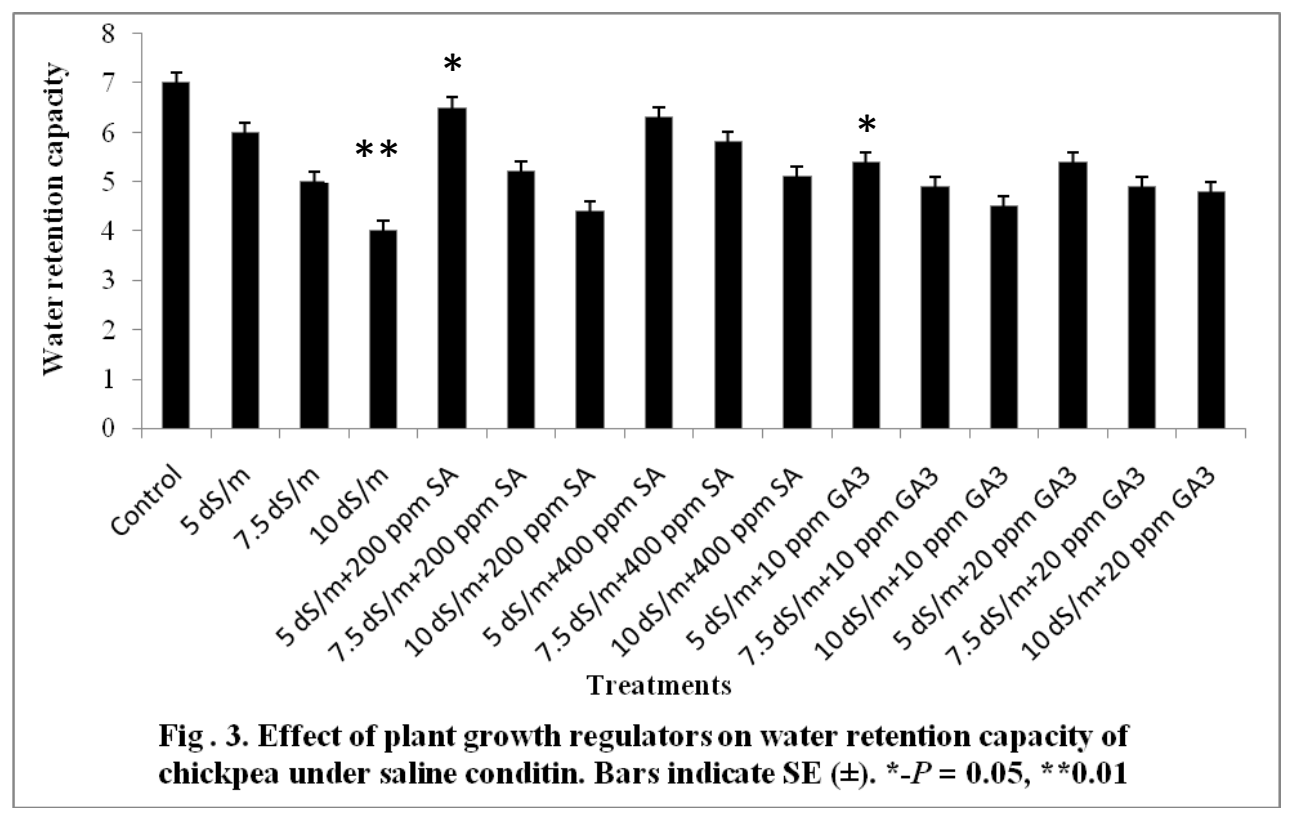

Chlorophyll content

Chlorophyll in chickpea leaf decreased as the salinity level increased and maximum reduction was observed at the highest salinity level $\left(10 \mathrm{dSm}^{-1}\right)$. Maximum chlorophyll content was recorded in plants grown under normal condition (Fig.4). The foliar application of SA and $\mathrm{GA}_{3}$ increased the chlorophyll level in salt treated plant but increasing rate was higher when plant was sprayed with lower doses of $\mathrm{SA}$ and $\mathrm{GA}_{3}$. The superior effects on chlorophyll content were recorded under the treatments of $\mathrm{SA}$ and $\mathrm{GA}_{3}$ at concentration of $200 \mathrm{ppm}$ and $10 \mathrm{ppm}$, respectively under lower salinity level $\left(5 \mathrm{dSm}^{-1}\right)$. Ghai et al. (2002) reported that the application of SA to the foliage of Brassica napus improved the chlorophyll content under salinity stress. An increase in chlorophyll content with $\mathrm{GA}_{3}$ was also reported earlier by Hayat et al. (2001).

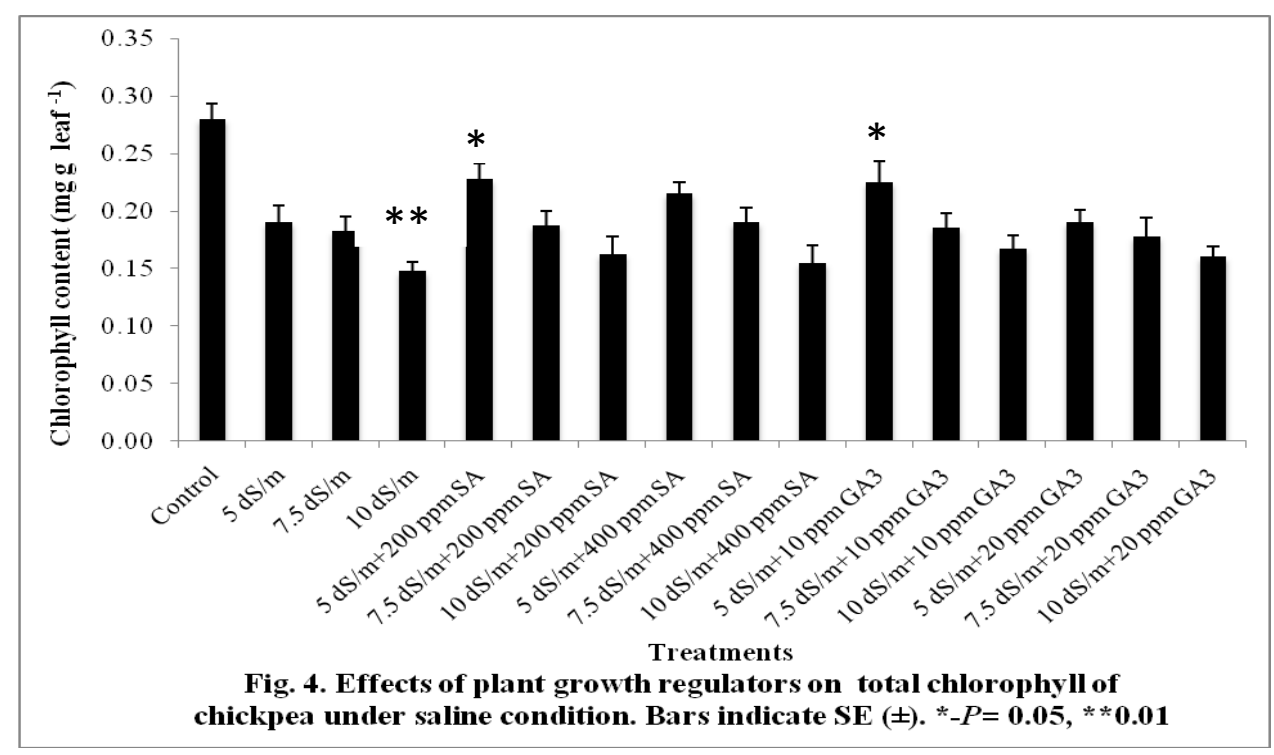


Hossain et al.

\section{Yield and yield contributing characters}

\section{Number of pod}

Pod number decreased with increasing salinity level. Lowest pod number (16.08) was found in plant irrigated with $10 \mathrm{dSm}^{1}$, which was $47 \%$ of the control plant (Table 1). However, pod number increased when plant was sprayed with $\mathrm{SA}$ and $\mathrm{GA}_{3}$ under saline condition. When plant was sprayed with SA @ 200 ppm under $5,7.5$ and $10 \mathrm{dSm}^{-1}$ saline water treated plant; number of pod was produced by chickpea 31, 21 and 16 which were 93\%, 63\% and 49\%, respectively compared to control. But it was $80 \%, 67 \%$ and $53 \%$, respectively when plant was sprayed with SA @ 400 ppm. On the other hand, when plant was sprayed with $\mathrm{GA}_{3} @ 10$ ppm under $5,7.5$ and $10 \mathrm{dSm}^{-1}$ saline water treated plant; number of pods per plant was produced by chickpea 30, 22 and 19 which were 89\%, 66\% and 55\%, respectively of the control. But it was $81 \%, 64 \%$ and $50 \%$, respectively when plant was sprayed with $\mathrm{GA}_{3} @ 20$ ppm. It is revealed that high concentration of $\mathrm{SA}$ and $\mathrm{GA}_{3}$ did not show significant ameliorative effect of salinity stress in chickpea in respect of number of pod.

\section{0-seed weight}

The highest seed weight per plant was found in non saline condition (24.88 g). Seed weight decreased when plant was irrigated with sea water and decreasing rate was higher with increasing salinity level. Lowest weight obtained $3.47 \mathrm{~g}$, which was $14 \%$ of the control when plant was irrigated with $10 \mathrm{dSm}^{-1}$ saline water (Table 1). However, seed weight increased when plant was sprayed with $\mathrm{SA}$ and $\mathrm{GA}_{3}$ under saline condition. When foliage was sprayed with $\mathrm{SA}$ @ 200 ppm under $5,7.5$ and $10 \mathrm{dSm}^{-1}$ saline water irrigated plant; 100 seed weight was produced by chickpea $18.76 \mathrm{~g}, 4.71 \mathrm{~g}$ and $2.52 \mathrm{~g}$ which were $75 \%, 19 \%$ and 10\%, respectively compared to control. But it was $69 \%, 22 \%$ and $14 \%$, respectively when plant was sprayed with SA @ 400 ppm. On the other hand, when plant was sprayed with $\mathrm{GA}_{3} @ 10$ ppm under $5,7.5$ and $10 \mathrm{dSm}^{-1}$ saline water irrigated plant; 100 seed weight was $17.30 \mathrm{~g}$, $5.61 \mathrm{~g}$ and $3.63 \mathrm{~g}$ which were $69 \%, 21 \%$ and 18\%, respectively of the control. But it was $73 \%, 22 \%$ and 14\%, respectively when plant was sprayed with $\mathrm{GA}_{3} @ 20 \mathrm{ppm}$. It is clear that high concentration of $\mathrm{SA}$ and $\mathrm{GA}_{3}$ did not show significant ameliorative effect of salinity stress in chickpea in relation to seed weight.

\section{Seed yield}

The highest amount of seed yield per plant was obtained from the control plants $(6.34 \mathrm{~g})$. Seed yield decreased when plant was irrigated with sea water and decreasing rate was higher with increasing salinity level. Lowest yield obtained $1.37 \mathrm{~g}$, which was $21 \%$ of the control when plant was irrigated with $10 \mathrm{dSm}^{-1}$ saline water (Table 1). However, seed yield was significantly increased when plant was sprayed with $\mathrm{SA}$ and $\mathrm{GA}_{3}$ under saline condition. When foliage was sprayed with SA @ 200 ppm under 5, 7.5 and $10 \mathrm{dSm}^{-1}$ saline water irrigated plant; seed yield was produced by chickpea $5.82 \mathrm{~g}, 2.23 \mathrm{~g}$ and $1.87 \mathrm{~g}$ which were 92\%, 35\% and 20\%, respectively compared to control. But it was $81 \%, 37 \%$ and $18 \%$, respectively when plant was sprayed with SA @ 400 ppm. On the other hand, when plant was sprayed with $\mathrm{GA}_{3} @ 10$ ppm under 5, 7.5 and $10 \mathrm{dSm}^{-1}$ saline water irrigated plant; seed yield per plant was $5.65 \mathrm{~g}$, $2.0 \mathrm{~g}$ and $1.28 \mathrm{~g}$ which were $89 \%, 31 \%$ and $20 \%$, respectively of the control. But it was $89 \%$, $25 \%$ and 19\%, respectively when plant was sprayed with $\mathrm{GA}_{3} @ 20$ ppm. It could be stated that the beneficial effect of SA on improving yield may be due to the translocation of more photo assimilates to the seeds. These results may be due to the role of salicylic acid in enhancing some physiological and biochemical aspects under stressful conditions (Maity and Bera, 2009). 
Salicylic Acid and Gibberelic Acid of Salinity on Chickpea

Table 1. Effects of plant growth regulators on seed yield and yield contributing characters of chickpea under salinity stress

\begin{tabular}{|c|c|c|c|}
\hline Treatments & $\begin{array}{l}\text { Number of } \\
\text { pod/plant }\end{array}$ & $\begin{array}{l}\text { 100-seed weight } \\
\text { (g) }\end{array}$ & $\begin{array}{l}\text { Seed yield/ plant } \\
\text { (g) }\end{array}$ \\
\hline Control (non saline) & 33.73 & 24.88 & 6.34 \\
\hline $5 \mathrm{dSm}^{-1}$ salinity & $26.99(80.01)^{*}$ & $16.93(68.04)$ & $4.75(74.92)$ \\
\hline $7.5 \mathrm{dSm}^{-1}$ salinity & $21.50(63.74)$ & $5.25(21.10)$ & $2.34(36.90)$ \\
\hline $10 \mathrm{dSm}^{-1}$ salinity & $16.08(47.67)$ & $3.47(13.94)$ & $1.37(21.60)$ \\
\hline $5 \mathrm{dSm}^{-1}$ salinity $+200 \mathrm{ppm} \mathrm{SA}$ & $31.63(93.77)$ & $18.76(75.40)$ & $5.82(91.79)$ \\
\hline $7.5 \mathrm{dSm}^{-1}$ salinity $+200 \mathrm{ppm} \mathrm{SA}$ & $21.47(63.65)$ & $4.71(18.93)$ & $2.23(35.17)$ \\
\hline $10 \mathrm{dSm}^{-1}$ salinity $+200 \mathrm{ppm} \mathrm{SA}$ & $16.40(48.61)$ & $2.52(10.12)$ & $1.27(20.03)$ \\
\hline $5 \mathrm{dSm}^{-1}$ salinity $+400 \mathrm{ppm} \mathrm{SA}$ & $27.21(80.67)$ & $17.30(69.53)$ & $5.17(81.54)$ \\
\hline $7.5 \mathrm{dSm}^{-1}$ salinity $+400 \mathrm{ppm} \mathrm{SA}$ & $22.88(67.83)$ & $5.61(22.54)$ & $2.38(37.53)$ \\
\hline $10 \mathrm{dSm}^{-1}$ salinity $+400 \mathrm{ppm}$ SA & $17.92(53.12)$ & $3.63(14.59)$ & $1.14(17.98)$ \\
\hline $5 \mathrm{dSm}^{-1}$ salinity $+10 \mathrm{ppm} \mathrm{GA}_{3}$ & $30.00(88.94)$ & $17.09(68.68)$ & $5.65(89.11)$ \\
\hline $7.5 \mathrm{dSm}^{-1}$ salinity+10 $\mathrm{ppm} \mathrm{GA}_{3}$ & $22.46(66.58)$ & $5.30(21.30)$ & $2.00(31.54)$ \\
\hline $10 \mathrm{dSm}^{-1}$ salinity+10 $\mathrm{ppm} \mathrm{GA}_{3}$ & $19.77(58.61)$ & $4.42(17.76)$ & $1.28(20.18)$ \\
\hline $5 \mathrm{dSm}^{-1}$ salinity $+20 \mathrm{ppm} \mathrm{GA}_{3}$ & $27.46(81.41)$ & $18.13(72.86)$ & $5.03(79.33)$ \\
\hline $7.5 \mathrm{dSm}^{-1}$ salinity $+20 \mathrm{ppm} \mathrm{GA}_{3}$ & $21.78(64.57)$ & $5.62(22.58)$ & $1.62(25.55)$ \\
\hline $10 \mathrm{dSm}^{-1}$ salinity $+20 \mathrm{ppm} \mathrm{GA}_{3}$ & $16.90(50.10)$ & $3.60(14.46)$ & $1.20(18.92)$ \\
\hline $\operatorname{LSD}(0.01)$ & 6.75 & 2.81 & 0.75 \\
\hline CV\% & 14.00 & 13.73 & 11.65 \\
\hline
\end{tabular}

*per cent of control

\section{Conclusion}

From the results it was concluded that salinity decreased dry matter production, chlorophyll content, water relation traits and yield of chickpea. Foliar application of SA and $\mathrm{GA}_{3} @ 200$ ppm and 10ppm, respectively alleviated the adverse effects of salinity at low level $\left(5 \mathrm{dSm}^{-1}\right)$. SA and $\mathrm{GA}_{3}$ at high concentration did not show appreciable performance to alleviate the adverse effect of salinity at high saline conditions. Therefore, $\mathrm{NaCl}$ induced reduction in the plant growth and yield of chickpea could be mitigated by exogenous application of plant growth regulators as $\mathrm{SA}$ and $\mathrm{GA}_{3}$ at low concentration under low salinity stress.

\section{Acknowledgement}

We are grateful to the Research Management Committee, Bangabandhu Sheikh Mujibur Rahman Agricultural University, Bangladesh for funding the study. 
Hossain et al.

\section{References}

Ahmad, P., C. A. Jelell, M. M. Azooz, and G. Nabi. 2009. Generation of ROS and non enzymatic anti-oxidants during abiotic stress in plants. Bot. Res. Int. 2: 11-20.

Ashraf, M. Y., K. Akhtar, G. Sarwar and M. Ashraf. 2002. Evaluation of arid and semi-arid ecotypes of guar (Cyamopsis tetragonoloba L.) for salinity $(\mathrm{NaCl})$ tolerance. Arid Environ. 52: 473-482.

Aydin, B. and B. Nalbantoglu. 2011. Effects of cold and salicylic acid treatments on nitrate reductase activity in spinach leaves. Turk. J. Biol. 35: 443-448.

Eraslan, F., A. Gunes, A. Inal, M. Alpaslan, E. G. Bagci, N. Cicek. 2007. Salicylic acid induced changes on some physiological parameters symptomatic for oxidative stress and mineral nutrition on maize (Zea mays L.) grown under salinity. J. Plant Physiol. 164: 728-736.

Ghai, N., R. C. Setia and N. Setia. 2002. Effects of peclobutrazol and salicylic acid on chlorophyll content, Hill activity and yield components in Brassica napus. Phytomorphology. 52: 82-87.

Gomez, K. A. and A. A. Gomez. 1984. Statistical procedures for agriculture research, 2nded, New York: John Wiley.

Hayat, Q., S. Hayat, M. Irfan and A. Ahmad. 2010. Effect of exogenous salicylic acid under changing environment: a review. Environ. Exp. Bot. 68(1): 14-25.

Hayat, S., A. Ahmad and M. Mobin. 2001. Carbonic anhydrase, photosynthesis and seed yield in mustard plants treated with phytohormones. Photosynthetica. 39: 111-114.

He Y. L., Y. L. Liu, Q. Chen and A. H. Bian. 2002. Thermo tolerance related to antioxidation induced by salicylic acid and heat hardening in tall fescue seedlings. J. Plant Physiol. Mol. Biol. 28: 89-95.

Hussein, M., M. L. K. Balbaa and M. S. Gaballah. 2007. Salicylic acid and salinity effects on growth of maize plants. Res. J. Agri. Biol. Sci. 3: 321-328.

Kaya, C., A. L. Tuna and I. Yokas. 2009. The Role of Plant Hormones in Plants under Salinity Stress. Springer, New York. P. 145.

Maggio, A., N. Barbieri, D. Raimondi and S. Pascale. 2010. Contrasting Effects of $\mathrm{GA}_{3}$ Treatments on Tomato Plants Exposed to Increasing Salinity. J. Plant Growth Regul. 29: 63-70.

Maity, U. and A. K. Bera. 2009. Effect of exogenous application of brassinolide and salicylic acid on certain physiological and biochemical aspects of gram green (Vigna radiataL. Wilcrek). Indian J. Agric. Res. 43: 194-199.

Manchanda, H. R., and S. K. Sharma.1990. Tolerance of Chloride and Sulfate salinity in chickpea (Cicer arietinum). J. Agric. Sci. 113: 407-410.

Schwechheimer, C. 2008. Understanding gibberellic acid signaling - are we there yet? Curr. Opin. Plant Biol. 11:9-15.

Witham, H., D. F. Blades and R. H. Devin.1986. Exercise in Plant Physiology (2 ${ }^{\text {nd }}$ Edition). PWS Publishers, Boston, USA. Pp. 128-131.

Yildirim, E., M. Turanand I. Guvenc. 2008. Effect of foliar salicylic acid applications on growth, chlorophyll and mineral content of cucumber (Cucumis sativus L.) grown under salt stress. J. Plant Nutr. 31: 593-612. 